\title{
ANALISIS KONSERVASI ENERGI PADA SISTEM PENCAHAYAAN DAN SISTEM PENDINGIN DI KANTOR SEKRETARIS DAERAH KABUPATEN GARUT
}

\author{
Sirli Nursabandi Illahi ${ }^{12}$, Edvin Priatna S.T., M.T. ${ }^{1}$, Nurul Hiron S.T.,M.Eng ${ }^{1}$ \\ Teknik Elektro, Fakultas Teknik, Universitas Siiwangi, Tasikmalaya, Indonesia ${ }^{1}$ \\ email: sirlinursabandi@gmail.com ${ }^{2}$
}

\begin{abstract}
Energy conservation in lighting systems and cooling systems aims to obtain optimal operation of energy usage without changing the function of the building, comfort and productivity of occupants, as well as considering aspects of environmental friendliness and cost. The results of observations in D and E buildings of the Garut Regional Secretary Office, almost all the rooms have lighting that does not appropriate the standard and humidity relative that exceeds the comfort factor of people in the room based on SNI. Based on the background of the problem, this study aims to look for conservation opportunities in lighting systems and cooling systems. The method used is an energy audit by calculating IKE, measuring the intensity of lighting and measuring temperature and humidity in some rooms. Based on the analysis results, the average IKE values in buildings D and E which are $1,1 \mathrm{kWh} / \mathrm{m}^{2} / \mathrm{month}$ and $2,54 \mathrm{kWh} / \mathrm{m}^{2} / \mathrm{month}$ are included in the highly efficient category based on Minister of Energy and Mineral Resources Regulation No. 13/2012. The energy conservation opportunity in this research is to redesign the artificial lighting system by replacing conventional TL lamps into LEDs and a total power of 2301,3 watts, then simulated in the DIALux software to get the assumption of average lux in accordance with the standard payback period of 4,5 years. For the cooling system, recalculating the heat load in occupied rooms is recommended for the replacement of air conditioners in conditioned rooms and the addition of AC in rooms that have not been conditioned with AC inverter and generated 6760 watts of power with a payback period of 27 months.
\end{abstract}

Keywords: : Energy Audit, Energy Consumption Intensity (IKE), Energy Conservation, Lighting Systems, Cooling Systems

\begin{abstract}
Abstrak
Konservasi energi pada sistem pencahayaan dan sistem pendingin bertujuan untuk memperoleh pengoperasian yang optimal pada pemakaian energi tanpa mengubah fungsi bangunan, kenyamanan dan produktivitas penghuni, serta mempertimbangkan aspek keramahan lingkungan dan biaya. Hasil observasi pada gedung D dan E Kantor Sekretaris Daerah Kabupaten Garut menunjukkan hampir semua ruangan memiliki pencahayaan yang tidak memenuhi standar dan kelembaban yang melebihi dari faktor kenyamanan orang di dalam ruangan berdasarkan SNI. Berdasarkan latar belakang masalah tersebut, penelitian ini bertujuan untuk mencari peluang konservasi pada sistem pencahayaan dan sistem pendingin. Metode yang digunakan adalah audit energi dengan menghitung IKE, mengukur intensitas pencahayaan, mengukur suhu dan kelembaban pada beberapa ruangan. Berdasarkan hasil analisis, nilai IKE rata-rata pada gedung D dan E yaitu $1,1 \mathrm{kWh} / \mathrm{m}^{2} /$ bulan dan $2,54 \mathrm{kWh} / \mathrm{m}^{2} /$ bulan masuk dalam kategori sangat efisien berdasarkan Peraturan menteri ESDM No. $13 / 2012$. Peluang konservasi energi pada penelitian ini adalah dengan perancangan ulang sistem pencahayaan buatan dengan mengganti lampu TL konvensional menjadi LED dengan total daya 2307,5 watt, kemudian disimulasikan pada software DIALux EVO 7.1 untuk mendapatkan asumsi rata-rata lux mendekati standar dengan payback period selama 4,5 tahun. Untuk sistem pendingin, berdasarkan penghitungan ulang beban kalor pada ruangan yang dihuni terdapat rekomendasi untuk penggantian AC pada ruangan yang telah terkondisi dan penambahan AC pada ruangan yang belum terkondisi dengan AC inverter dan dihasilkan daya total 6760 watt dengan payback period selama 27 bulan.
\end{abstract}

Kata Kunci : Audit Energi, Intensitas Konsumsi Energi (IKE), Konservasi Energi, Sistem Pencahayaan, Sistem Pendingin

\section{PENDAHULUAN}

Era globalisasi dan modernisasi yang ditandai dengan pesatnya perkembangan teknologi yang mendukung kehidupan manusia, diikuti pula dengan meningkatnya pemakaian energi pada berbagai sektor kehidupan manusia ${ }^{[1]}$ Dengan meningkatnya pemakaian energi, usaha efisiensi energi khusunya pada gedung pemerintah semakin penting untuk dilakukan mengingat terbatasnya sumber energi primer di Indonesia.

Kantor Sekretaris Daerah Kabupaten Garut merupakan salah satu kantor yang menjalani fungsi dalam hal mengatur pemerintahan dan melayani masyarakat Kabupaten Garut. Di dalam gedung pemerintahan dibutuhkan fasilitas-fasilitas yang menggunakan energi listrik seperti sistem penerangan, sistem pendingin/AC, komputer, printer dan lain lain untuk menunjang aktivitas pejabat pemerintah. Pada gedung $\mathrm{D}$ dan E kantor SEKDA yang merupakan objek penelitian menggunakan sumber energi listrik yang berasal dari PLN sebesar 6600 VA dan 5500 VA dengan golongan tarif P1. Pada kedua gedung ini terdapat beberapa bagian yaitu bagian Unit Layanan Pengadaan (ULP), Bagian Pengendalian Bangunan (DALBANG), Bagian Perlengkapan, Bagian Perekonomian dan Bagian Sandi Telekomunikasi. Bangunan memiliki luas gedung 434,4 $\mathrm{m}^{2}$ dan $463,12 \mathrm{~m}^{2}$ dengan material secara umum berupa dinding bata, struktur beton bertulang dengan kaca di beberapa sisi. Dilihat dari data konsumsi energi listrik pada 1 tahun terakhir terhitung ratarata pemakaian nya cukup stabil dan efisien pada kedua gedung tersebut walaupun pada bulan-bulan tertentu terdapat penaikan. Namun setelah observasi lapangan, khususnya pada pengukuran intensitas penerangan masih banyak ruangan yang tidak sesuai dengan SNI dan persentase kelembaban suhu di dalam gedung cukup besar dapat mengurangi kenyamanan karyawan yang berada di dalam gedung.

Tidak dapat dipungkiri bahwa dalam fungsional sistem penerangan dan sistem pendingin yang merupakan fasilitas 
dengan daya beban yang mendominasi seringkali mengalami kerusakan atau turunnya performa karena umur peralatan yang sudah terlalu tua atau kurangnya perawatan yang dilakukan. Hal tersebut dapat berpengaruh pada efisiensi energi, kenyamanan, serta produktivitas karyawan dalam bekerja. Untuk mengatasi masalah tersebut, perlu dilakukan analisis pada sistem penerangan buatan dan pendingin agar dapat mencapai konservasi energi. Konservasi energi yang dimaksud adalah suatu upaya pengelola gedung untuk mencapai pengoperasian yang optimal khususnya pada sistem pencahayaan dan sistem pendingin seperti pada peraturan menteri ESDM nomor 13 tahun 2012 yang menyatakan bahwa dalam rangka meningkatkan penghematan pemakaian tenaga listrik, perlu dilakukan pemakaian tenaga listrik secara efisien dan rasional, tanpa mengurangi keselamatan, kenyamanan, dan produktivitas $^{[3]}$. Kemudian peraturan menteri ESDM nomor 14 tahun 2012 yang secara garis besar menyatakan bahwa manajemen energi adalah kegiatan terpadu untuk mengendalikan konsumsi energi agar tercapai pemanfaatan energi yang efektif dan efisien ${ }^{[4]}$.

Secara sederhana, metode yang dilakukan pada penelitian ini dapat dibagi menjadi 3 tahap. Tahap pertama yakni audit awal dengan dilakukannya pengumpulan data historis konsumsi energi pada satu tahun terakhir dan luas bangunan objek penelitian untuk mencari IKE. Kemudian tahap kedua dan ketiga adalah pengukuran yang kemudian hasilnya di analisa untuk mendapatkan peluang konservasi energi khusunya pada sistem pencahayaan dan sistem pendingin yang dapat diterapkan pada bangunan gedung.

\section{Batasan Masalah}

Batasan-batasan masalah pada penyusunan Tugas Akhir ini antara lain :

1. Penelitian ini hanya dilakukan pada gedung D dan E Kantor Sekretaris Daerah Kabupaten Garut pada bulan Mei 2019.

2. Instalasi sistem kelistrikan tidak diperhitungkan.

3. Kondisi cuaca pada saat pengukuran dianggap stabil.

4. Penghitungan nilai IKE menggunakan data historis penggunaan konsumsi energi.

5. Dalam mencari peluang konservasi di khususkan pada sistem penerangan buatan dan sistem pendingin.

\section{BAHAN \& METODE}

\section{Audit Energi}

Audit energi dibagi menjadi tiga jenis yaitu audit energi singkat, audit energi awal, dan audit energi rinci. Pada penelitian ini jenis audit yang dilakukan adalah audit energi rinci yang meliputi pengumpulan data historis, data luas bangunan gedung, observasi dan pengukuran, perhitungan IKE dan kecenderungannya, potensi penghematan energi, analisis teknis dan finansial. Salah satu tahapan dalam pelaksanaan audit energi adalah perhitungan nilai Intensitas Konsumsi Energi. IKE memiliki persamaan sebagai berikut

$$
I K E=\frac{k W h \text { total }\left(\frac{k W h}{\text { bulan }}\right)}{\text { Luas Total }\left(m^{2}\right)}(1)
$$

Dengan kriteria nilai IKE sebagai berikut:
Tabel 1. Kriteria Nilai IKE Listrik berdasarkan Peraturan Menteri ESDM No. 13/2012

\begin{tabular}{|c|c|c|c|}
\hline No & $\begin{array}{c}\text { Dengan AC } \\
\left(\mathrm{kWh} / \mathrm{m}^{2} / \mathrm{bu}\right. \\
\text { lan })\end{array}$ & $\begin{array}{c}\text { Tanpa AC } \\
\left(\mathrm{kWh} / \mathrm{m}^{2} / \mathrm{bul}\right. \\
\text { an })\end{array}$ & Kriteria \\
\hline 1. & $<8,5$ & $<3,4$ & $\begin{array}{c}\text { Sangat } \\
\text { efisien }\end{array}$ \\
\hline 2. & $8,5-14$ & $3,4-5,6$ & Efisien \\
\hline 3. & $14-18,5$ & $5,6-7,4$ & $\begin{array}{c}\text { Cukup } \\
\text { Efisien }\end{array}$ \\
\hline 4. & $>18,5$ & $>7,4$ & Boros \\
\hline
\end{tabular}

\section{Konservasi Energi pada Sistem Pencahayaan}

Konservasi energi pada sistem pencahayaan bertujuan untuk memperoleh sistem pencahayaan dengan pengoperasian yang optimal.. Sistem pencahayaan pada suatu bangunan terdiri atas sistem pencahayaan alami dan buatan. Pencahayaan alami adalah pencahayaan yang berasal dari cahaya matahari dan harus dapat dimanfaatkan sebaikbaiknya untuk mengurangi energi listrik pada bangunan ${ }^{[5]}$. Pencahayaan alami memiliki dampak terhadap meningkatnya suhu ruangan dikarenakan radiasi matahari. Pencahayaan buatan merupakan pencahayaan yang dihasilkan oleh sumber cahaya buatan manusia. Pencahayaan buatan diperlukan apabila posisi ruangan sulit dicapai oleh pencahayaan alami. Perancangan pencahayaan buatan di perkantoran harus mengacu pada nilai yang ditentukan pada SNI 036197:2011 seperti yang ditampilkan di tabel 2 dan tabel 3.

Tabel 2. Nilai Acuan Tingkat Pencahayaan

\begin{tabular}{|l|c|}
\hline \multicolumn{1}{|c|}{ Fungsi Ruangan } & $\begin{array}{c}\text { Tingkat Pencahayaan } \\
\text { (Lux) }\end{array}$ \\
\hline Ruang Resepsionis & 300 \\
\hline Ruang Direktur & 350 \\
\hline Ruang Kerja & 350 \\
\hline Ruang Komputer & 350 \\
\hline Ruang Rapat & 300 \\
\hline Ruang Gambar & 750 \\
\hline Gudang Arsip & 150 \\
\hline Ruang Arsip Aktif & 300 \\
\hline Tangga Darurat & 150 \\
\hline Tempat Parkir & 100 \\
\hline
\end{tabular}

Tabel 3. Daya Maksimum

\begin{tabular}{|l|c|}
\hline \multicolumn{1}{|c|}{ Fungsi Ruangan } & $\left(\mathrm{W} / \mathrm{m}^{2}\right)$ \\
\hline Ruang Resepsionis & 13 \\
\hline Ruang Direktur & 13 \\
\hline
\end{tabular}




\begin{tabular}{|l|c|}
\hline Ruang Kerja & 12 \\
\hline Ruang Komputer & 12 \\
\hline Ruang Rapat & 12 \\
\hline Ruang Gambar & 20 \\
\hline Gudang Arsip & 6 \\
\hline Ruang Arsip Aktif & 12 \\
\hline Tangga Darurat & 4 \\
\hline Tempat Parkir & 4 \\
\hline
\end{tabular}

Perhitungan untuk mengetahui jumlah lampu yang dibutuhkan adalah sebagai berikut:

$$
n=\frac{E \times A}{\operatorname{Kp} \times \operatorname{Kd} \times F}(2)
$$

$\mathrm{N}$ merupakan jumlah lampu yang digunakan, nilai $\mathrm{E}$ merupakan nilai acuan intensitas pencahayaan (lux), A merupakan luas ruangan dalam $\mathrm{m}^{2}$. Kp merupakan koefisien penggunaan dengan nilai 0,8 dan $\mathrm{Kd}$ merupakan koefisien depresiasi dengan nilai 0,8 sedangakn nilai $\mathrm{F}$ merupakan lumen keluaran lampu. Setelah melakukan penghitungan ulang titik lampu/kebutuhan lampu pada setiap ruangan, akan dilakukan simulasi pada software DIALux untuk mendapatkan jenis lampu yang akan digunakan untuk memenuhi standar pencahayaan.

\section{Konservasi Energi pada Sistem Pendingin}

Konservasi energi sistem tata udara bertujuan untuk mengidentifikasi dan mencari peluang penghematan energi dari sistem tata udara tanpa mengurangi persyaratan kenyamanan termal, kualitas udara ruang dan/atau menurunkan kerja alat ${ }^{[6]}$. Untuk memenuhi kenyamanan termal pengguna bangunan, kondisi perencanaan gedung yang berada di wilayah dataran tinggi atau pegunungan, dengan suhu udara maksimum rata-rata sekitar $28^{\circ} \mathrm{C} \mathrm{DB}$ dan $24^{\circ} \mathrm{C}$ atau kurang (atau suhu rata-rata bulanan sekitar $23^{\circ} \mathrm{C}$ ), pada umumnya tidak diperlukan pengkondisian udara buatan. Pencapaian kenyamanan termal dan ketersediaan udara bersih seutuhnya dibebankan kepada optimalisasi rancangan arsitektur secara pasif ${ }^{[2]}$.

Adapun faktor yang mempengaruhi kenyamanan termal orang dibagi menjadi dua. 1) Temperatur udara kering; Sejuk nyaman, antara temperature efektif $20,5^{\circ} \mathrm{C}$ $22,8^{\circ} \mathrm{C}$; Nyaman optimal, antara temperature efektif $22,8^{\circ} \mathrm{C}$ $-25,8^{\circ} \mathrm{C}$; Hangat nyaman, antara temperature efektif $25,8^{\circ} \mathrm{C}$ - $27,1^{\circ} \mathrm{C}$. 2) Kelembaban Relatif; Untuk daerah tropis dianjurkan antara 40\% 50\% dan untuk ruangan yang jumlah orangnya padat seperti ruang pertemuan, kelembaban udara relative masih diperbolehkan berkisar antara 55\% $60 \%$. Untuk mencari peluang konservasi pada sistem pendingin perlu dilakukan penghitungan beban kalor yang dikeluarkan pada ruangan dengan menggunakan beberapa persamaan berikut; ${ }^{[9]}$

$$
\begin{aligned}
& \text { Q } \\
& \mathrm{Q}_{\text {atap }} \quad=\mathrm{A} \times \text { koef transmisi kalor } \mathrm{K} \text { dari atap } \mathrm{x} \\
& \text { (to-t1) (4) } \\
& \mathrm{Q}_{\text {sensible orang }}=\text { jumlah orang } \times 250(5)
\end{aligned}
$$

$$
\begin{array}{ll}
\mathrm{Q}_{\text {laten orang }} & =\text { jumlah orang } \times 200(6) \\
\mathrm{Q}_{\text {equipment }} & =\frac{n \times P \times 0,860}{1000}(7) \\
\mathrm{Q}_{\text {jendela }} & =\text { Ajendela } \times \text { koefisien transmisi kalor } \mathrm{x} \\
& \Delta \mathrm{t}(8) \\
\mathrm{Q}_{\text {dinding }} & =\text { Adinding } \times 2,15\left(\mathrm{t}_{0}-\mathrm{t}_{1}\right)(9) \\
\mathrm{Q}_{\text {infiltrasi }} & =\frac{P \times L \times T A C \times 35,31}{60}(10) \\
\mathrm{Q}_{\text {ventilasi }} & =\left[\left(\mathrm{t}_{0}-\mathrm{t}_{1}\right) \cdot 1,08+\left(\mathrm{RH}_{0}-\mathrm{RH}_{1}\right) .0,67\right](11) \\
\mathrm{Q}_{\text {total }} & =\mathrm{Q}_{\text {lampu }}+\mathrm{Q}_{\text {atap }}+\mathrm{Q}_{\text {sensible orang }}+\mathrm{Q}_{\text {laten orang }} \\
& +\mathrm{Q}_{\text {equipment }}+\mathrm{Q}_{\text {jendela }}+\mathrm{Q}_{\text {dinding }}+\mathrm{Q}_{\text {infiltrasi }}+ \\
& \mathrm{Q}_{\text {ventilasi }}(12)
\end{array}
$$

\section{Payback Period}

Suatu persamaan yang digunakan untuk mengetahui jangka waktu pengembalian nilai investasi melalui penerimaan kas bersih dalam sebuah periode tertentu. ${ }^{[8]}$

$$
n={ }^{(1 / 1+i)} \log \left(1-\frac{i . P V}{A}\right)(13)
$$

$\mathrm{n}=$ payback period (bulan)

$\mathrm{i}=$ suku bunga Indonesia per periode (juli $2019=$ $5,75 \% /$ tahun $=0,479 \%$ per bulan).

$\mathrm{pV}=$ asumsi penggunaan $\mathrm{kWh}$ perbulan

$\mathrm{A}=$ biaya investasi

Penelitian ini dilakukan berdasarkan diagram alir pada gambar 1

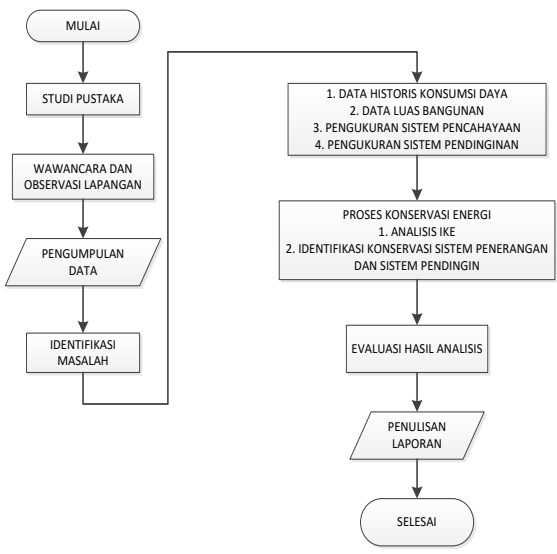

Gambar 1. Diagram Alir Penelitian

a. Pengumpulan Data

Pada tahapan audit ini dibagi menjadi 2 tahap pelaksanaan pengumpulan data yaitu:

- Pengumpulan data tanpa pengukuran berupa data konsumsi energi pada gedung D dan E 1 tahun terakhir, luas bangunan, dan data peralatan listrik yang digunakan untuk penunjang pekerjaan.

- Pengumpulan data pengukuran dengan melakukan pengukuran pada tiap ruangan. Variabel yang dibutuhkan adalah intensitas pencahayaan(lux), suhu\&kelembaban pada beberapa ruangan.

b. Lokasi Penelitian

Lokasi penelitian adalah gedung D dan E Kantor Sekretaris Daerah Kabupaten Garut. Bangunan ini memiliki luas gedung 434,4 $\mathrm{m}^{2}$ dan 463,12 $\mathrm{m}^{2}$ dengan material secara umum berupa dinding bata, struktur beton bertulang dengan kaca di beberapa sisi.

c. Analisis Data 
Data yang diperoleh kemudian di analisis untuk mendapatkan peluang konservasi energi dengan menggunakan acuan yang ada pada bagian landasan teori

\section{HASIL DAN PEMBAHASAN}

\section{Penghitungan IKE}

Bangunan gedung D dan E masing-masing terdiri atas 2 lantai dengan total luas bangunan 434,4 $\mathrm{m}^{2}$ dan 463,12 $\mathrm{m}^{2}$. Data historis konsumsi energi listrik dan penghitungan IKE ditunjukkan gambar 2 dan gambar 5.

Konsumsi Energi

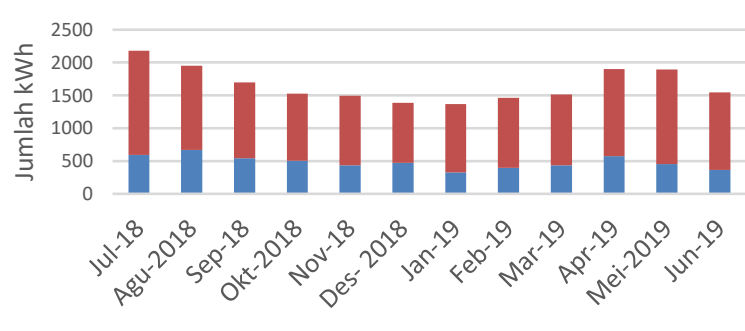

Bulan

Eumlah kWH Gedung D Eumlah kWH Gedung E

Gambar 2. Grafik Konsumsi Energi

\section{Grafik IKE}

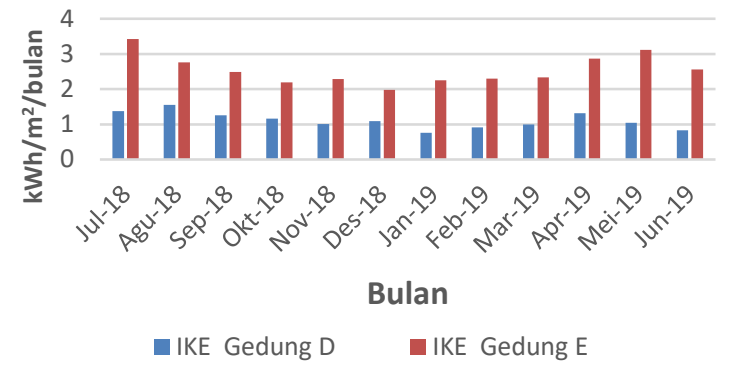

Gambar 3. Grafik IKE

Berdasarkan nilai IKE pada grafik gambar 2 pada gedung D dan E di bawah nilai standar $3,4 \mathrm{kWh} / \mathrm{m}^{2} /$ bulan dapat di klasifikasikan sangat efisien untuk bangunan dengan AC maupun non AC.

\section{Konservasi Sistem Pencahayaan}

Beban pencahayaan buatan yang digunakan rata-rata adalah jenis lampu TL Dropceiling 18 watt, LED bulb 9 dan 3 watt, downlight 18 watt dan tornado 24 watt. Pengukuran intensitas pencahayaan dilakukan langsung di objek penelitian dengan menggunakan titik pengukuran penerangan umum(pengukuran seluruh area ruangan) titik potong garis horizontal panjang dan lebar ruangan pada setiap jarak 1 meter setinggi 1 meter/0,75 meter dari lantai atau setara tinggi meja kantor. ${ }^{[7]}$ Hasil pengukuran intensitas pencahayaan dan daya maksimum pada ruangan ditunjukkan pada tabel 4.
Tabel 4. Hasil pengukuran lux dan daya maksimum

\begin{tabular}{|c|c|c|c|c|}
\hline Area & Ruang & $\begin{array}{c}\text { Lux } \\
\text { Average }\end{array}$ & $\begin{array}{l}\text { Luas } \\
\left(\mathrm{m}^{2}\right)\end{array}$ & $\begin{array}{c}\text { Daya } \\
\left(\mathrm{W} / \mathrm{m}^{2}\right)\end{array}$ \\
\hline \multirow{9}{*}{ D1 } & R. Kabag & 51,49 & 24 & 0,75 \\
\hline & Ruang staff & 78,8 & 24 & 1,37 \\
\hline & Ruang tamu & 132,82 & 24 & 0,75 \\
\hline & Toilet 1 & 42 & 3,75 & 0,8 \\
\hline & Toilet 2 & 42 & 3,75 & 08 \\
\hline & Toilet 3 & 42 & 3,75 & 0,8 \\
\hline & Toilet 4 & 42 & 4,8 & 0,63 \\
\hline & Ruang arsip & 41,04 & 24 & 0,75 \\
\hline & Pantry & 5,67 & 13,2 & 1,36 \\
\hline \multirow{7}{*}{ D2 } & Ruang rapat & 149,5 & 24 & 7,50 \\
\hline & Pantry & 199 & 4,5 & 4 \\
\hline & Mushola & 64,83 & 7,5 & 2,40 \\
\hline & Koridor & 60 & 30 & 3,00 \\
\hline & Ruang staff & 125,84 & 73,5 & 3,43 \\
\hline & R. kasubag 1 & 268,42 & 9 & 2,00 \\
\hline & R. kasubag 2 & 309,58 & 9 & 2,00 \\
\hline \multirow{7}{*}{ E1.a } & R. Kabag & 81,37 & 14,47 & 1,24 \\
\hline & Ruang tamu & 57,67 & 16,42 & 1,10 \\
\hline & Ruang Staff & 125,9 & 48,24 & 0,75 \\
\hline & Toilet 1 & 64,3 & 1,57 & 1,91 \\
\hline & Toilet 2 & 36,67 & 3,45 & 0,87 \\
\hline & Toilet 3 & 53,3 & 2,81 & 1,07 \\
\hline & Koridor & 266,7 & 10,77 & 2,23 \\
\hline \multirow{6}{*}{ E1.b } & Ruang tamu & 75,91 & 10,16 & 1,77 \\
\hline & Ruang Rapat & 64,91 & 19,66 & 4,58 \\
\hline & R. Kabag & 134,056 & 12,8 & 4,22 \\
\hline & Ruang staff & 123.76 & 62,97 & 4,72 \\
\hline & Mushola & 96 & 4,74 & 1,90 \\
\hline & Toilet & 84,5 & 2,5 & 1,20 \\
\hline \multirow{4}{*}{ E2.a } & R. Kabag & 131,45 & 16,09 & 1,95 \\
\hline & Ruang staff & 76,26 & 83,56 & 4,95 \\
\hline & Ruang rapat & 77,56 & 12,85 & 8,40 \\
\hline & Pantry & 29,56 & 7,65 & 4,71 \\
\hline \multirow{6}{*}{ E2.b } & R. Kabag & 98,03 & 12,8 & 2,81 \\
\hline & Ruang staff 1 & 70,32 & 38,94 & 3,70 \\
\hline & Ruang staff 2 & 147,2 & 8,1 & 8,89 \\
\hline & R. kasubag & 646,5 & 7,29 & 2,47 \\
\hline & Mushola & 90 & 7 & 2,50 \\
\hline & Koridor & 98,04 & 32,14 & 2,24 \\
\hline
\end{tabular}

Karena nilai yang didapatkan setelah pengukuran hampir semua tidak sesuai standar dan untuk penghitungan daya maksimum masih dibawah standar, maka peluang konservasi dapat dilakukan dengan penggantian lampu dengan daya yang lebih besar namun tetap mempertimbangkan hasil daya maksimum per ruangan supaya tetap efisien. Untuk mendapat rekomendasi penggantian atau penambahan lampu dilakukan simulasi perangkat lunak DIALux EVO 7.1. Semua lampu yang simulasikan menggunakan lampu LED tube, LED Bulb, dan TL LED dengan menyesuaikan kebutuhan tiap ruangan sampai mendapatkan nilai Lux yang diinginkan dan daya maksimum yang tetap efisien. Hasil simulasi pada DIALux dapat dilihat pada Tabel 5.

Tabel 5. Hasil Analisis Dialux 


\begin{tabular}{|c|c|c|c|c|}
\hline Area & Ruang & Lumen & $\begin{array}{c}\text { Lux } \\
\text { average }\end{array}$ & $\operatorname{Daya}\left(\mathrm{W} / \mathrm{m}^{2}\right)$ \\
\hline \multirow{9}{*}{ D1 } & R. kabag & 2300 & 354 & 3,17 \\
\hline & Koridor & 2300 & 139 & 1,08 \\
\hline & R. staff 1 & 2300 & 372 & 4,75 \\
\hline & R. tamu & 2300 & 198 & 1,58 \\
\hline & Toilet 1 & 1230 & 262 & 3,07 \\
\hline & Toilet 2 & 1230 & 270 & 3,07 \\
\hline & Toilet 3 & 1230 & 255 & 3,07 \\
\hline & Toilet 4 & 1230 & 240 & 2,4 \\
\hline & R. arsip & 2300 & 206 & 1,58 \\
\hline \multirow{9}{*}{ D2 } & \multirow[t]{2}{*}{ R. rapat } & 1230 & \multirow{2}{*}{387} & \multirow{2}{*}{69,7} \\
\hline & & 2300 & & \\
\hline & Pantry & 2300 & 283 & 4,22 \\
\hline & Mushola & 2300 & 199 & 2,53 \\
\hline & Koridor & 1230 & 162 & 2,3 \\
\hline & R. staff 2 & 2500 & 350 & 3,33 \\
\hline & R. kasubag 1 & 2500 & 349 & 4,22 \\
\hline & R. kasubag 2 & 2500 & 351 & 4,22 \\
\hline & Ruang OB & 2300 & 275 & 2,53 \\
\hline \multirow{7}{*}{ E1.a } & kabag + staff & 3400 & \multirow{2}{*}{371} & 2,92 \\
\hline & & 3400 & & 3,98 \\
\hline & R. tamu & 2300 & 142 & 1,21 \\
\hline & Toilet 1 & 1230 & 263 & 7,32 \\
\hline & Toilet 2 & 1230 & 240 & 0,03 \\
\hline & Toilet 3 & 1230 & 291 & 0,04 \\
\hline & Koridor & 1230 & 84.8 & 1,07 \\
\hline \multirow{9}{*}{ E1.b } & R. tamu & 2300 & 174 & 1,72 \\
\hline & \multirow[t]{2}{*}{ R. Rapat } & 2300 & \multirow{2}{*}{344} & \multirow{2}{*}{4,11} \\
\hline & & 1000 & & \\
\hline & \multirow[t]{2}{*}{ R. kabag } & 1230 & \multirow{2}{*}{403} & \multirow{2}{*}{4,9} \\
\hline & & 2300 & & \\
\hline & \multirow[t]{2}{*}{ R. staff } & 2300 & \multirow{2}{*}{349} & \multirow{2}{*}{4,9} \\
\hline & & 1230 & & \\
\hline & Mushola & 2300 & 275 & 4,01 \\
\hline & Toilet & 1230 & 247 & 4,6 \\
\hline \multirow{6}{*}{ E2.a } & \multirow[t]{2}{*}{ R. kabag } & 806 & \multirow{2}{*}{382} & \multirow{2}{*}{4,03} \\
\hline & & 2300 & & \\
\hline & R. staff & 2300 & 353 & 2,93 \\
\hline & \multirow[t]{2}{*}{ R. rapat } & 2300 & \multirow{2}{*}{384} & \\
\hline & & 806 & & 4,32 \\
\hline & Pantry & 2300 & 240 & 2,48 \\
\hline & R. kabag & 3400 & 376 & 3,75 \\
\hline & R. staff 1 & 2300 & 388 & 3,15 \\
\hline & R. staff 2 & 2300 & 341 & 4,32 \\
\hline E2.b & R. PABX & 1230 & 260 & 2,37 \\
\hline & R. kasubag & 3100 & 340 & 5,9 \\
\hline & Mushola & 2300 & 230 & 2,71 \\
\hline & Koridor & 2300 & 184 & 1,09 \\
\hline
\end{tabular}

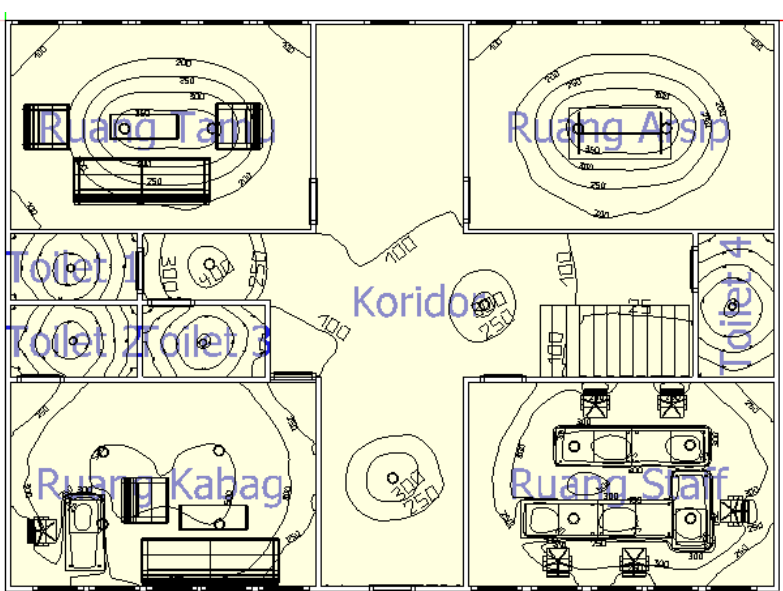

Gambar 4. Penyebaran cahaya hasil simulasi D1

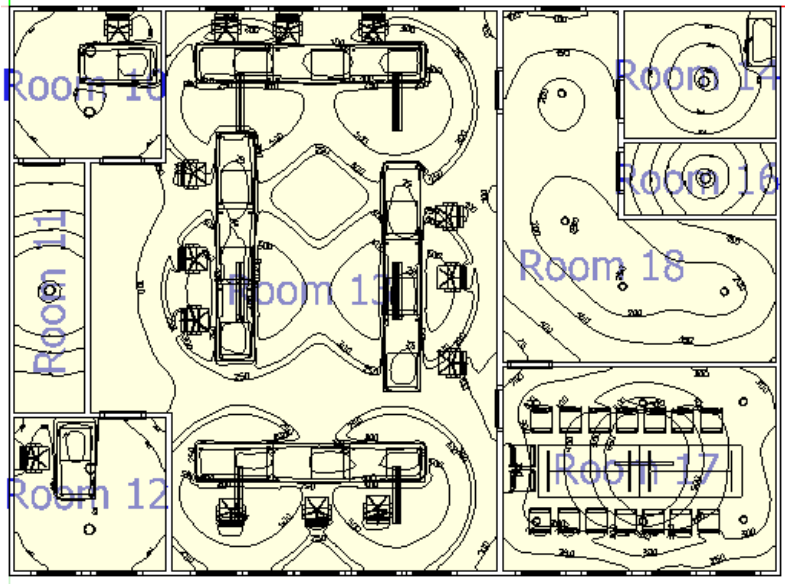

Gambar 5. Penyebaran cahaya hasil simulasi D2

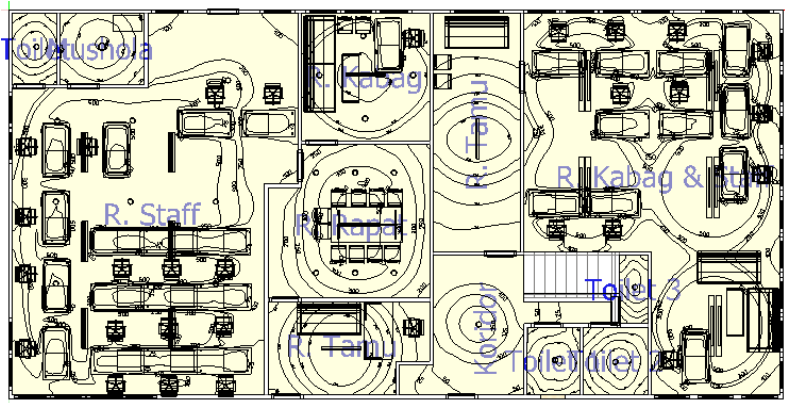

Gambar 6. Penyebaran cahaya hasil simulasi E1

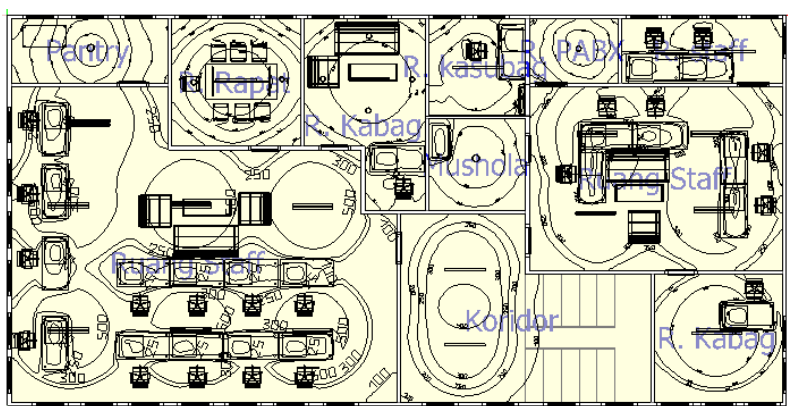

Gambar 7. Penyebaran cahaya hasil simulasi E2

\section{Payback Period}

Pada tabel 6 ditunjukkan rekomendasi jenis dan besaran lampu Philips LED untuk perancangan ulang sistem pencahayaan yang telah di simulasikan di DIALux EVO 
yang kemudian akan dihitung untuk mendapatkan perkiraan rentang waktu payback period.

Tabel 6. Rekomendasi Lampu Philips dan Biaya

\begin{tabular}{|c|l|c|c|c|}
\hline Area & \multicolumn{1}{|c|}{$\begin{array}{c}\text { Jenis } \\
\text { Lampu }\end{array}$} & $\begin{array}{c}\text { Daya } \\
(\mathrm{w})\end{array}$ & Jumlah & Biaya (Rp) \\
\hline \multirow{5}{*}{ D } & $\begin{array}{l}\text { Classic } \\
\text { LED Bulb }\end{array}$ & 11 & 14 & 41.000 \\
\cline { 2 - 5 } & $\begin{array}{l}\text { Master } \\
\text { LEDtube } \\
\text { InstantFit } \\
\text { HF T8 }\end{array}$ & 17,5 & 15 & 300.000 \\
\cline { 2 - 5 } & $\begin{array}{l}\text { Corepro } \\
\text { LEDBulb }\end{array}$ & 19 & 24 & 62.000 \\
\hline \multirow{5}{*}{ E } & $\begin{array}{l}\text { Corepro } \\
\text { LEDBulb }\end{array}$ & 9,5 & 14 & 32.000 \\
\cline { 2 - 5 } & $\begin{array}{l}\text { Corepro } \\
\text { LEDBulb }\end{array}$ & 19 & 3 & 62.000 \\
\cline { 2 - 5 } & $\begin{array}{l}\text { Master } \\
\text { LEDtube } \\
\text { InstantFit } \\
\text { HF T8 }\end{array}$ & 17,5 & 44 & 300.000 \\
\cline { 2 - 5 } & $\begin{array}{l}\text { Master } \\
\text { LEDtube } \\
\text { InstantFit } \\
\text { HF T8 }\end{array}$ & 24 & 12 & 470.000 \\
\cline { 2 - 5 } & $\begin{array}{l}\text { Classic } \\
\text { LED Bulb }\end{array}$ & 11 & 17 & 41.000 \\
\hline \multirow{7}{*}{ Total } & 2307,5 watt & 26.733 .000 \\
\hline
\end{tabular}

Kapasitas daya lampu gedung existing $=2316$ watt

Kapasitas energi lampu gedung existing

Nyala 24 jam $=12,96 \mathrm{kWh} /$ bulan

Nyala selama jam kerja (asumsi 7 jam $)=298,725 \mathrm{kWh} / \mathrm{bulan}$

Nyala Ketika dibutuhkan (asumsi 4 jam) $=59,1 \mathrm{kWh} / \mathrm{bulan}$

Kapasitas Daya Lampu Gedung Perancangan Ulang = 2307,5 watt

Kapasitas Energi Lampu Gedung Perancangan Ulang Nyala 24 jam $=6,9 \mathrm{kWh} / \mathrm{bulan}$

Nyala selama jam kerja (asumsi 7 jam $)=316,64 \mathrm{kWh} / \mathrm{bulan}$ Nyala Ketika dibutuhkan (asumsi 4 jam) $=59,69 \mathrm{kWh} /$ bulan Total $=6,9+316,64+59,69=383,23 \mathrm{kWh} /$ bulan

Blok LWBP $=$ Daya perbulan $(\mathrm{kWh}) \times$ tarif energi $(\mathrm{Rp})$ $=383,23 \times 1467,28=\operatorname{Rp} 562,305$

$\mathrm{n}={ }^{(1 / 1+\mathrm{i})} \log \left(1-\frac{\mathrm{i} . \mathrm{PV}}{\mathrm{A}}\right)$

$\mathrm{n}={ }^{(1 / 1+0,00479)} \log \left(1-\frac{0,00479.26733000}{562305}\right)$

$\mathrm{n}={ }^{(0,99523)} \log (1-0,22772)$

$\mathrm{n}={ }^{(0,99523)} \log (0,77228)$

$\mathrm{n}=\frac{\log (0,77228)}{\log (0,99523)}$

$\mathrm{n}=\frac{-0,11222}{-0,00207}$

$\mathrm{n}=54$ bulan atau kurang lebih 4,5 tahun

\section{Perbandingan Total Daya Lampu}
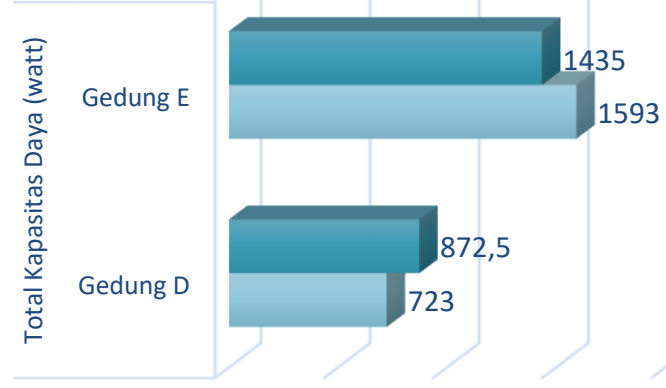

$\begin{array}{lllll}0 & 500 & 1000 & 1500 & 2000\end{array}$

Perancangan Ulang Exisitng

Gambar 8. Perbandingan Total Daya Lampu

\section{Konservasi Pada Sistem Pendingin}

Pada objek penelitian, hanya gedung $\mathrm{E}$ yang di dalamnya terdapat beberapa ruangan yang memiliki pendingin diantaranya di bagian DALBANG terdapat di ruangan kepala bagian, ruang rapat, dan 2 di ruang staff. Selanjutnya di bagian SANDITEL terdapat di ruangan staf kecil (operator) dan ruang PABX. Dalam penelitian ini, ruang $\mathrm{PABX}$ tidak diperhitungkan karena tidak digunakan untuk beraktivitas. Pengukuran suhu dan kelembaban dilakukan satu kali dengan menggunakan temperature alarm sebagai sampel di semua ruangan yang sudah terkondisi dan di beberapa ruangan lain yang belum terkondisi AC dan suhu kelembaban luar ruangan $\left(\mathrm{T}_{0}\right.$ dan $\left.\mathrm{RH}_{0}\right)$ untuk pembanding. Hasil pengukuran suhu dan kelembaban dapat dilihat pada tabel 7 .

Tabel 7. Hasil pengukuran suhu dan kelembaban $\left(\mathrm{t}_{1} \& \mathrm{RH}_{1}\right)$ dan $\left(\mathrm{t}_{0} \& \mathrm{RH}_{0}\right)$ pada 17 Juni 2019, jam 11.00 - 11.30 WIB

\begin{tabular}{|c|c|c|c|c|}
\hline Nama Ruangan & $\mathrm{T}_{0}$ & $\mathrm{~T}_{1}$ & $\mathrm{RH}_{0}$ & $\mathrm{RH}_{1}$ \\
\hline $\begin{array}{c}\text { Ruang Staff } \\
\text { Perlengkapan }\end{array}$ & $28^{\circ} \mathrm{C}$ & $24^{\circ} \mathrm{C}$ & $77 \%$ & $75 \%$ \\
\hline $\begin{array}{c}\text { Ruang staff ULP } \\
\text { Bawah }\end{array}$ & $28^{\circ} \mathrm{C}$ & $24,1^{\circ} \mathrm{C}$ & $77 \%$ & $70 \%$ \\
\hline Ruang Staff Sanditel & $28^{\circ} \mathrm{C}$ & $24,5^{\circ} \mathrm{C}$ & $77 \%$ & $69 \%$ \\
\hline $\begin{array}{c}\text { Ruang staff ULP } \\
\text { Atas }\end{array}$ & $28^{\circ} \mathrm{C}$ & $25.6^{\circ} \mathrm{C}$ & $77 \%$ & $67 \%$ \\
\hline
\end{tabular}

Tabel 7. Lanjutan

\begin{tabular}{|c|c|c|c|c|}
\hline $\begin{array}{c}\text { Ruang Staff } \\
\text { Perekonomian }\end{array}$ & $28^{\circ} \mathrm{C}$ & $24,5^{\circ} \mathrm{C}$ & $77 \%$ & $71 \%$ \\
\hline $\begin{array}{c}\text { Ruang Staff } \\
\text { DALBANG }\end{array}$ & $28^{\circ} \mathrm{C}$ & $24,4^{\circ} \mathrm{C}$ & $77 \%$ & $70 \%$ \\
\hline $\begin{array}{c}\text { Ruang Kabag } \\
\text { DALBANG }\end{array}$ & $28^{\circ} \mathrm{C}$ & $24,8^{\circ} \mathrm{C}$ & $77 \%$ & $72 \%$ \\
\hline $\begin{array}{c}\text { Ruang Rapat } \\
\text { DALBANG }\end{array}$ & $28^{\circ} \mathrm{C}$ & $24,7^{\circ} \mathrm{C}$ & $77 \%$ & $70 \%$ \\
\hline
\end{tabular}

Setelah mendapatkan hasil pengukuran suhu dan kelembaban selanjutnya dilakukan penghitungan beban kalor dengan menggunakan persamaan yang telah di 
cantumkan pada bagian landasan teori. Hasil perhitungan beban kalor dapat dilihat di tabel 8 .

Tabel 8. Penghitungan Beban Kalor

\begin{tabular}{|c|c|c|c|}
\hline No. & $\begin{array}{c}\text { Nama } \\
\text { Ruangan }\end{array}$ & $\begin{array}{c}\text { Beban } \\
\text { kalor } \\
(\mathrm{BTU} / \mathrm{h})\end{array}$ & $\begin{array}{c}\text { Kapasitas AC } \\
\text { existing } \\
(\mathrm{BTU} / \mathrm{h})\end{array}$ \\
\hline 1. & $\begin{array}{c}\text { Ruang Kepala } \\
\text { Bagian } \\
\text { DALBANG }\end{array}$ & 1778,077 & 7000 \\
\hline 2. & $\begin{array}{c}\text { Ruang Staff } \\
\text { DALBANG }\end{array}$ & 10973,13 & 14000 \\
\hline 3. & $\begin{array}{c}\text { Ruang Rapat } \\
\text { DALBANG }\end{array}$ & 7389,768 & 9000 \\
\hline 4. & $\begin{array}{c}\text { Ruang Staff } \\
\text { SANDITEL }\end{array}$ & 1904,43 & 12000 \\
\hline
\end{tabular}

Pada hasil perhitungan pada tabel 8 menunjukkan bahwa beban kalor yang dihasilkan lebih kecil dari kapasitas AC yang terpasang pada ruangan tersebut. Pada ruangan kepala bagian DALBANG dan ruang staff SANDITEL terdapat beban pendingin yang terlalu besar yang dapat menyebabkan konsumsi energi menjadi boros dan memerlukan penyesuaian yaitu dengan mengganti AC dari 1 1/2 PK menjadi 1/2 PK. Kemudian hasil perhitungan beban kalor di ruangan yang belum menggunakan AC beserta rekomendasi besaran AC yang disesuaikan dapat dilihat di tabel 9.

Tabel 9. Beban kalor dan Kebutuhan AC

\begin{tabular}{|c|c|c|c|}
\hline No. & Nama Ruangan & $\begin{array}{c}\text { Kalor } \\
(\mathrm{BTU} / \mathrm{h})\end{array}$ & $\begin{array}{c}\text { Kebutuhan } \\
\text { AC }(\mathrm{PK})\end{array}$ \\
\hline 5. & $\begin{array}{c}\text { Ruang Staff } \\
\text { Perlengkapan }\end{array}$ & 10140,19 & $1,27 \sim 1 \frac{1}{2} 2$ \\
\hline 6. & $\begin{array}{c}\text { Ruang Staff ULP } \\
\text { D1 }\end{array}$ & 7371,92 & $0,93 \sim 1$ \\
\hline 7. & $\begin{array}{r}\text { Ruang Staff ULP } \\
\text { D2 }\end{array}$ & 13954,25 & $1,74 \sim 2$ \\
\hline 8. & $\begin{array}{c}\text { Ruang Staff } \\
\text { Perekonomian }\end{array}$ & 13851,18 & $1,73 \sim 2$ \\
\hline
\end{tabular}

\section{Payback Period}

Di bawah ini terdapat tabel untuk rekomendasi AC yang dapat digunakan dengan penghitungan payback period nya.
Tabel 10. Rekomendasi Jenis AC Panasonic

\begin{tabular}{|c|c|c|c|c|c|}
\hline Nama Ruang & $\begin{array}{l}\mathrm{P} \\
\mathrm{K}\end{array}$ & $\begin{array}{l}\mathrm{Jm} \\
1\end{array}$ & $\begin{array}{c}\text { Daya } \\
\text { (watt } \\
\text { ) }\end{array}$ & Model & $\begin{array}{l}\text { Harga } \\
(\mathrm{Rp})\end{array}$ \\
\hline $\begin{array}{l}\text { Kabag } \\
\text { DALBANG }\end{array}$ & $1 / 2$ & 1 & 320 & $\begin{array}{l}\text { Deluxe } \\
\text { Alowa }\end{array}$ & 4.025 .000 \\
\hline $\begin{array}{l}\text { Staff } \\
\text { DALBANG }\end{array}$ & $\begin{array}{c}1 \\
1 / 2\end{array}$ & 1 & 990 & $\begin{array}{c}\text { PU- } \\
12 \mathrm{TKP}\end{array}$ & 6.100 .000 \\
\hline $\begin{array}{l}\text { Rapat } \\
\text { DALBANG }\end{array}$ & 1 & 1 & 690 & $\begin{array}{c}\text { CS- } \\
\text { PU9UK } \\
\text { P }\end{array}$ & 5.150 .000 \\
\hline $\begin{array}{l}\text { Staff } \\
\text { SANDITEL }\end{array}$ & $1 / 2$ & 1 & 320 & $\begin{array}{l}\text { Deluxe } \\
\text { Alowa }\end{array}$ & 4.025 .000 \\
\hline $\begin{array}{l}\text { Staff } \\
\text { Perlengkapa } \\
\text { n }\end{array}$ & $\begin{array}{c}1 \\
1 / 2\end{array}$ & 1 & 990 & $\begin{array}{c}\text { PU- } \\
12 \mathrm{TKP}\end{array}$ & 6.100 .000 \\
\hline $\begin{array}{l}\text { Staff ULP } \\
\text { D1 }\end{array}$ & 1 & 1 & 690 & $\begin{array}{c}\text { CS- } \\
\text { PU9UK } \\
\text { P }\end{array}$ & 5.150 .000 \\
\hline $\begin{array}{l}\text { Staff ULP } \\
\text { D2 }\end{array}$ & 1 & 2 & 690 & $\begin{array}{c}\text { CS- } \\
\text { PU9UK } \\
\text { P }\end{array}$ & 5.150 .000 \\
\hline $\begin{array}{l}\text { Staff } \\
\text { Perekonomia } \\
\text { n }\end{array}$ & 1 & 2 & 690 & $\begin{array}{c}\text { CS- } \\
\text { PU9UK } \\
\text { P }\end{array}$ & 5.150 .000 \\
\hline \multicolumn{2}{|l|}{ Total } & \multicolumn{2}{|c|}{6760} & & $\begin{array}{c}51.150 .00 \\
0\end{array}$ \\
\hline
\end{tabular}

Kapasitas Daya AC Gedung Existing = 4210 watt Kapasitas Energi AC Gedung Existing

Nyala 24 jam $=288 \mathrm{kWh} /$ bulan

Nyala selama jam kerja (asumsi 7 jam $)=414,75 \mathrm{kWh} /$ bulan Nyala ketika dibutuhkan saja (asumsi 4 jam $)=84 \mathrm{kWh} / \mathrm{bulan}$

Kapasitas Daya AC Perancangan Ulang = 6760 watt Kapasitas Energi Lampu Gedung Perancangan Ulang Nyala $24 \mathrm{jam}=288 \mathrm{kWh} /$ bulan

Nyala selama jam kerja (asumsi 7 jam $)=1038,25 \mathrm{kWh} / \mathrm{bulan}$ Nyala Ketika dibutuhkan (asumsi 4 jam) $=69 \mathrm{kWh} /$ bulan Total $=288+1038,25+69=1395,25 \mathrm{kWh} /$ bulan Blok LWBP $=$ Daya perbulan $(\mathrm{kWh}) \times$ tarif energi $(\mathrm{Rp})$

$$
=1395,25 \times 1467,28=\operatorname{Rp} 2.047 .222
$$

$\mathrm{n}={ }^{(1 / 1+\mathrm{i})} \log \left(1-\frac{\mathrm{i} \cdot \mathrm{PV}}{\mathrm{A}}\right)$

$\mathrm{n}={ }^{(1 / 1+0,00479)} \log \left(1-\frac{0,00479.51150000}{2047222}\right)$

$\mathrm{n}={ }^{(0,99523)} \log (1-0,11967)$ 
$\mathrm{n}={ }^{(0,99523)} \log (0,88033)$

$\mathrm{n}=\frac{\log (0,88033)}{\log (0,99523)}$

$\mathrm{n}=\frac{-0,05535}{-0,00207}$

$\mathrm{n}=26,74$ bulan $\sim 27$ bulan

\section{Perbandingan Total Daya AC}

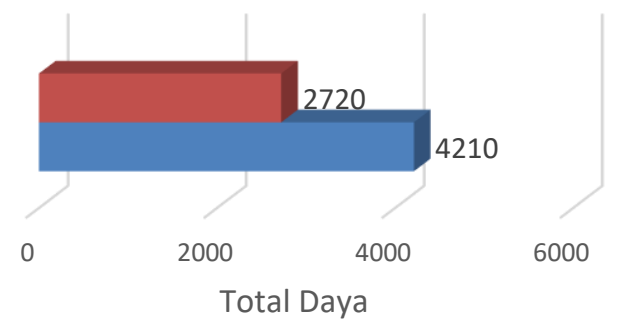

- Perancangan Ulang Exisitng

Gambar 9. Perbandingan Daya AC existing dan baru

\section{KESIMPULAN}

1. IKE gedung D dan E Kantor Sekretaris Daerah Kabupaten Garut masuk pada kriteria sangat efisien dengan nilai maksimum $1,55 \mathrm{kWh} / \mathrm{m}^{2} /$ bulan untuk gedung D dan $3,4 \mathrm{kWh} / \mathrm{m}^{2} /$ bulan untuk gedung E.

2. Pada pengukuran intensitas pencahayaan menunjukkan hampir semua ruangan tidak memenuhi standar SNI sehingga diperlukan mencari peluang untuk konservasi energi yaitu mengganti lampu TL Konvensional dengan lampu LED. Pengukuran suhu pada beberapa ruangan yang dihuni oleh karyawan menunjukkan angka sesuai standar namun kelembaban yang terukur pada saat bersamaan menunjukkan angka lebih dari $65 \%$ yang berarti kelembaban di dalam ruangan tersebut tidak memenuhi standar SNI.

3. Hasil dari simulasi pada software DIALux menunjukkan adanya perubahan nilai lux mendekati angka pada standar SNI dengan asumsi penggunaan energi sebanyak 382,83 $\mathrm{kWh} /$ bulan dari existing $370,785 \mathrm{kWh} /$ bulan dan payback period yang didapat dengan mempertimbangkan biaya investasi adalah sekitar 4,5 tahun. Hasil penghitungan menunjukkan beban kalor yang dihasilkan lebih kecil dari kapasitas AC yang terpasang, namun pada ruang staff bagian SANDITEL dan ruang kepala bagian DALBANG, AC yang terpasang memiliki daya terlalu besar yang dapat menyebabkan konsumsi energi menjadi boros. Konservasi yang dapat dilakukan adalah dengan tidak menyalakan AC apabila tidak dibutuhkan dan mengganti AC dengan yang lebih hemat energi. Kemudian pada ruangan yang belum terkondisikan oleh AC, apabila dibutuhkan dapat dipasang AC dengan menyesuaikan beban kalor yang dikeluarkan dengan AC yang lebih hemat energi. payback period pada investasi penambahan AC ini kurang lebih selama 27 bulan dan total daya menjadi 6760 watt.

\section{REFERENSI}

[1] Avrin Nur Widiastuti. "Audit Energi pada Gedung Departemen Teknik Arsitektur dan Perencanaan FT UGM”. 2017.

[2] Standar Nasional Indonesia. Tata Cara Perancangan Sistem Ventilasi dan Pengkondisian Udara pada Bangunan Gedung. Jakarta: Badan Standarisasi Nasional, 2001

[3] Republik Indonesia. Peraturan Menteri Energi dan Sumber Daya Mineral Nomor 13 Tahun 2012 tentang Penghematan Pemakaian Tenaga Listrik. Jakarta: Kementerian Hukum dan Hak Asasi Manusia, 2012.

[4] Republik Indonesia. Peraturan Menteri Energi dan Sumber Daya Mineral Nomor 14 Tahun 2012 tentang Manajemen Energi. Jakarta: Kementerian Hukum dan Hak Asasi Manusia, 2012.

[5] Standar Nasional Indonesia. Konservasi energi pada sistem pencahayaan. Jakarta: Badan Standarisasi Nasional, 2011.

[6] Badan Standarisasi Nasional, Standar Nasional Indonesia. Konservasi energi sistem tata udara bangunan gedung. Jakarta: 2011.

[7] Standar Nasional Indonesia. Pengukuran Intensitas Penerangan di Tempat Kerja. Jakarta: Badan Standarisasi Nasional, 2004.

[8] Meisita Adelina Damanik. "Implementasi Aspek Green Building pada Bangunan Jurusan Teknik Elektro dan Teknologi Informasi UGM’'. 2015

[9] S. Juwana, Jimmy. 2005. Panduan Sistem Bangunan Tinggi. Jakarta: Penerbit Erlangga 